\title{
ІНДИВІДУАЛЬНЕ СПРИЙНЯТТЯ ЧАСУ - РАННЯ ПРОГНОСТИЧНА ОЗНАКА РОЗВИТКУ ЗАХВОРЮВАНЬ
}

Тернопільський національний медичний університет

імені І. Я. Горбачевського МОЗ України, м. Тернопіль, Україна

\begin{abstract}
Мета: виявити ризик розвитку захворювань в осіб молодого віку за показником індивідуального сприйняття часу.
Матеріали і методи. Проведено анкетування 200 осіб жіночої та чоловічої статей віком від 18 до 22 років (по 100 осіб у кожній групі) для виявлення факторів ризику та визначення показника індивідуального сприйняття часу (т) за методом Б. Й. Цуканова. В анкеті згруповано питання щодо фракторів ризику патології серцево-судинної системи, сечовидільної системи, шлунково-кишкового тракту.

Результати. У осіб чоловічої статі із $\tau=0,7-0,8 \in$ більший ризик захворіти на хвороби шлунково-кишкового тракту, оскільки вони частіше і в більшій кількості вживають алкоголь, частіше мають надлишкову масу тіла та піддаються стресовим впливам. Ймовірно більший ризик розвитку артеріальної гіпертензії при $\tau=0,8-0,86$ існує в осіб жіночої статі. У осіб чоловічої статі з $\mathrm{t}=0,86-0,94$ більший ризик розвитку ниркової патології порівняно із особами жіночої статі, тому що вони зазнають частішого переохолодження та вживають більше води, тим самим збільшуючи навантаження на нирки. Більша схильність до гіподинамії, переважання тютюнокуріння, споживання надлишку солоної їжі та достовірно обтяжений спадковий анамнез щодо серцево-судинної патології при $\tau=0,94-1,00$ у осіб чоловічої статі свідчить про високий ризик розвитку в них у майбутньому патології серцево-судинної системи (ішемічної хвороби серця та цереброваскулярних захворювань).

Висновки. Отримані результати вказують на наявність зв'язку певних фракторів ризику розвитку захворювань 3 т-типом респондентів. Визначення у подальшому в пацієнтів т-типу дозволить спрогнозувати ризик розвитку певної патології та запропонувати їм комплекс індивідуальних профрілактичних заходів.
\end{abstract}

КЛЮчОВІ СЛОВА: показник індивідуального сприйняття часу (т-тип); захворюваність; прогноз; серцевосудинна патологія.

Упродовж останніх років спостерігають збільшення та «помолодшання» більшості соматичних хвороб. Особливо це стосується неінфекційних захворювань, які, за даними ВООЗ, становлять 86 \% усіх смертей і 77 \% тяжкості хвороб у Європейському регіоні $[2,8,9]$. Здатність виявляти можливі ризики розвитку захворювань на основі новітніх методів і засобів та розробляти шляхи їх усунення $€$ важливою рисою сучасної медичної допомоги.

Відображення часу $є$ невід'ємною складовою частиною світосприйняття. Діяльність людини від народження організована у часі й від цього залежить рівень адаптації особи до навколишнього середовища. Відображення часу пов'язане 3 рівнем обміну речовин, руховою активністю, 3 пам'яттю і забезпечується корою великих півкуль за участю підкіркових систем, зокрема лівою півкулею [1]. Індивідуальне сприйняття часу залежить від психологічного стану особи. Так, при середній тривожності спостерігається незначне відхилення від еталона, при низькій - недооцінка та перевідмірювання інтервалів (довша індивідуальна хвилина), при високій - переоцінка і недовідмірювання (коротка індивідуальна хвилина). Використання результатів оцінювання часу для визначення емоційного стану рекомендовано при стресах [4]. Суб'єктивна внутрішня оцінка часу $є$ одним із параметрів, що характеризують дію стресора. За її величиною можна в цілому скласти уявлення про адаптаційні можливості людини. Індивідуальне сприйняття часу залежить від віку, статі, погодних умов [3]. У людей 3 артеріальною гіпертензією менша тривалість часу, що є психологічним стресором і прогностичним фрактором розвитку ішемічної хвороби серця [6].

Мета дослідження: виявити ризик розвитку захворювань в осіб молодого віку за показником індивідуального сприйняття часу.

Матеріали і методи. Проведено анкетування 200 осіб жіночої та чоловічої статей віком від 18 до 22 років (по 100 осіб у кожній групі) для виявлення фракторів ризику (ФР) та визначення

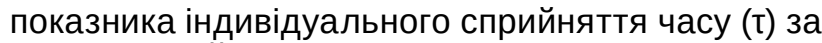
методом Б. Й. Цуканова $[5,7]$. Суть цього методу полягає в наступному: обстежуваним пропонують подумки відрахувати певні проміжки часу (в секундах). Паралельно із цим іде відлік часу на механічному секундомірі. Потім дані зіставляють та вираховують показник індивідуального сприйняття часу (т-тип). 
В анкеті згруповано питання щодо фракторів ризику виникнення захворювань:

- загальні питання стосувалися фракторів ризику розвитку неінфекційних захворювань, а саме: тютюнокуріння, рухової активності, вживання алкоголю, наявності хронічних захворювань, стресів;

- питання, які вивчали фрактори ризику розвитку патології серцево-судинної системи, а саме: рівень артеріального тиску, обтяжений анамнез щодо серцево-судинної патології;

- питання, які вивчали фрактори ризику розвитку патології сечовидільної системи, а саме: споживання солоної, молочнокислої їжі, наявність переохолодження та/або частих простуд, частота вживання мінеральної води;

- питання, які вивчали фрактори ризику розвитку патології печінки та жовчного міхура, а саме: споживання гострої та жирної їжі;

- питання, які вивчали фрактори ризику розвитку патології шлунка, а саме: приймання нестероїдних протизапальних препаратів та споживання прянощів.

Усі студенти були інформовані про конфріденційність проведених обстежень. Обстеження проводили з дотриманням норм біоетики.
Статистичну обробку результатів здійснювали на персональному комп'ютері 3 використанням пакета ліцензованих прикладних програм Statistica 10.0 та MS Excel XP.

Результати дослідження та їх обговорення. За даними Б. Й. Цуканова, в осіб із хронічними неінфекційними захворюваннями (хворобами серця, печінки, нирок, шлунка тощо) існує зв'язок між їх локалізацією та певними типологічними групами суцільного спектра «т-типів». Існує 5 проміжків «т-типів» від 0,7 до 1,1. Особи із захворюваннями печінки і жовчного міхура (гепатит, холецистит) мають т 0,7-0,8. В осіб із захворюваннями серцево-судинної системи (ішемічна хвороба серця) т становить 0,8-0,86. Серед осіб із захворюваннями нирок (пієлонефрити, гіпертензія ниркового типу, нирковокам'яна хвороба) т дорівнює 0,86-0,94. Особам із захворюваннями системи кровообігу (ішемічна хвороба серця, інсульт) притаманний т від 0,94 до 1,0, особам із хворобами шлунка (виразка, диспепсичні явища) т - від 1,0 до 1,1.

Серед обстежених студентів виділено 5 груп із певними показниками індивідуального сприйняття часу (табл. 1).

\section{Таблиця 1. Поділ респондентів щодо показника індивідуального сприйняття часу та статі}

\begin{tabular}{|c|c|c|c|}
\hline$\tau$ & Ризик & жінки (\%) & чоловіки (\%) \\
\hline $0,7-0,8$ & $\begin{array}{l}\text { Особи, в яких є ризик розвитку хвороб печінки і } \\
\text { жовчного міхура (гепатит, холецистит) }\end{array}$ & 23 & 16 \\
\hline $0,8-0,86$ & $\begin{array}{l}\text { Особи, в яких є ризик розвитку хвороб серцево- } \\
\text { судинної системи (ішемічна хвороба серця) }\end{array}$ & 22 & 19 \\
\hline $0,86-0,94$ & $\begin{array}{l}\text { Особи, в яких є ризик розвитку хвороб нирок } \\
\text { (пієлонефрити, гіпертензія ниркового типу, } \\
\text { нирковокам'яна хвороба) }\end{array}$ & 23 & 17 \\
\hline $0,94-1,00$ & $\begin{array}{l}\text { Особи, в яких є ризик розвитку хвороб серцево- } \\
\text { судинної системи, мозку (ішемічна хвороба серця, } \\
\text { інсульт) }\end{array}$ & 14 & 21 \\
\hline $1-1,1$ & $\begin{array}{l}\text { Особи, в яких є ризик розвитку хвороб шлунка } \\
\text { (виразка, диспепсичні явища) }\end{array}$ & 18 & 27 \\
\hline
\end{tabular}

Серед респондентів із $\tau=0,7-0,8$ виявлено наступне: $15,78 \%$ осіб жіночої статі та 42,85\% осіб чоловічої статі цієї групи мають надлишкову масу тіла. Більшість респондентів жіночої статі даної групи вживає алкоголь. Вживають алкоголь 100 \% осіб чоловічої статі. Споживання жирної їжі та фраст-фрудів в обох статей приблизно однакове. Особи чоловічої статі достовірно частіше піддаються стресам під час навчання або вдома, зокрема $(28,57 \pm 12,07) \%(p=0,032)$, на відміну від осіб жіночої статі, у яких такої достовірності не виявлено. Також зі всіх опитуваних даної групи $(10,53 \pm 7,04) \%$ осіб жіночої статі та $(14,29 \pm 9,35) \%$ осіб чоловічої статі вже мають хронічні захворювання шлунково-кишкового тракту.
Особи із т=0,8-0,86 також віддають перевагу алкоголю, проте респонденти чоловічої статі частіше його вживають $((52,94 \pm 12,11) \%)$, ніж респонденти жіночої статі $((33,33 \pm 11,11) \%)$. Близько третини осіб чоловічої статі $((29,41 \pm 11,05)$ \%) ведуть переважно сидячий спосіб життя та в основному використовують транспорт. У цей же ж самий час тільки незначна частина осіб жіночої статі $((5,56 \pm 5,56) \%)$ веде сидячий спосіб життя. Кількість осіб жіночої статі, які не курять, в рази перевищує кількість осіб чоловічої статі $((66,67 \pm 11,43) \%$ проти $(29,41 \pm 11,05) \%)$. В обох статей наявні стресові ситуації під час навчання або вдома $((27,78 \pm 10,86) \%$ - часто, $(61,11 \pm 11,82) \% \quad-$ 
іноді в осіб жіночої статі та $(11,76 \pm 7,81) \%$ і $(76,47 \pm 10,29) \%$, відповідно, в осіб чоловічої статі). Як ми бачимо, кількість осіб жіночої статі, які часто зазнають стресу, більша, ніж осіб чоловічої статі. Отримані результати вказують на ймовірно більший ризик розвитку артеріальної гіпертензії саме у них. Серед респондентів чоловічої статі $(52,94 \pm 12,11) \%$ достовірно часто споживають жирну їжу та фраст-фруди $(p=0,041)$, порівняно 3 респондентами жіночої статі, де її вживають лише 11,11 \% обстежених. Особи жіночої статі часто $((16,67 \pm 9,04) \%)$ та постійно $((11,11 \pm 7,62) \%)$ споживають солону їжу, тоді як особи чоловічої статі - лише іноді $((88,24 \pm 7,81) \%)$. У $2 / 3$ обстежених осіб жіночої статі та чверті осіб чоловічої статі даної групи студентів обтяжений генетичний анамнез із боку серцево-судинних захворювань.

Серед осіб із $\tau=0,86-0,94$ респонденти чоловічої статі більше зазнають переохолодження $((66,67 \pm 12,17) \%)$, порівняно із респондентами жіночої статі $((47,37 \pm 11,45)$ \%). Також більшість осіб чоловічої $((92,91 \pm 12,88) \%)$ та жіночої $((47,37 \pm 11,45) \%)$ статей іноді споживає велику кількість молока і молочнокислих продуктів. Як ми можемо побачити, частота осіб чоловічої статі, які часто вживають багато води, більша, ніж жіночої (53,33 \% проти 26,00 \% відповідно).

Опитувані групи осіб із $\tau=0,94-1,00$ мають практично однакову шкідливу звичку вживати алкоголь. Усі респонденти жіночої статі займаються руховою активністю, тоді як у $(15,79 \pm 8,37) \%$ осіб чоловічої статі така звичка відсутня. $(47,37 \pm 10,66) \%$ респондентів чоловічої та $(12,5 \pm 11,69) \%$ жіночої статей викурюють менше 10 сигарет на день. Усі респонденти жіночої статі даної групи зазнають стресу під час навчання або вдома, тоді як у осіб чоловічої статі стрес наявний тільки у $68 \%$. Як особи чоловічої статі, так і жіночої однаково часто споживають жирну їжу та фаст-фуди. Практично всі респонденти чоловічої статі $((94,74 \pm 9,35) \%)$ та більшість жіночої $((62,50 \pm$ $17,68) \%$ споживають солону їжу. У достовірної більшості осіб чоловічої статі $((42,11 \pm 11,33) \%$, $\mathrm{p}=0,011)$, як і у жіночої $((62,5 \pm 17,12) \%)$ спадковий анамнез обтяжений серцево-судинними захворюваннями, які наявні у близьких родичів. Вказані чинники у респондентів чоловічої статі (більша схильність до гіподинамії, переважання тютюнокуріння, споживання надлишку солоної їжі та достовірно обтяжений спадковий анамнез щодо серцево-судинної патології) при $\tau=0,94-$ 1,00 свідчить про високий ризик розвитку в них у майбутньому патології серцево-судинної системи (ішемічної хвороби серця та цереброваскулярних захворювань).

Більшість обстежених осіб чоловічої статі 3 т=1-1,1 курить цигарки, тоді як у осіб жіночої статі ця шкідлива звичка відсутня. Респонденти жіночої статі із цієї групи достовірно часто додають в їжу спеції та прянощі $((71,43 \pm 12,53) \%$, $\mathrm{p}=0,0363)$, чоловічої ж споживають менше спецій (тільки $(58,33 \pm 10,06) \%$ ). Усі особи жіночої статі та достовірна більшість респондентів чоловічої статі $((87,50 \pm 6,75) \%, p=0,034)$ даної групи піддаються стресовим впливам. Більшість осіб жіночої $((64,29 \pm 13,29) \%)$ та чоловічої $((58,33 \pm 10,06) \%)$ статей іноді приймає нестероїдні протизапальні препарати.

Отже, в процесі обстеження виявлено, що вже у молодому віці в осіб із певними показниками індивідуального сприйняття часу $€$ фрактори ризику, які в процесі життя можуть спричинити виникнення відповідної хвороби. Виключення факторів ризику зможе зменшити або запобігти виникненню хвороби.

\section{Висновки}

1. У осіб чоловічої статі $3 \mathrm{\tau}=0,7-0,8 \in$ більший ризик захворіти на хвороби шлунково-кишкового тракту, оскільки вони частіше і в більшій кількості вживають алкоголь, частіше мають надлишкову масу тіла та піддаються стресовим впливам. Про це свідчить більший відсоток вже наявних хронічних захворювань в осіб чоловічої статі порівняно із жіночою $((14,29 \pm 9,35) \%$ та $(10,53 \pm 7,04) \%$ відповідно).

2. У респондентів чоловічої статі $3 \mathrm{t}=0,86$ 0,94 більший ризик розвитку ниркової патології порівняно із особами жіночої статі, тому що вони зазнають частішого переохолодження та вживають більше води, тим самим збільшуючи навантаження на нирки.

3. У молодому віці у частини осіб наявні хронічні захворювання, що свідчить про «помолодшання» більшості соматичних захворювань.

4. Отримані результати вказують на наявність зв'язку певних фракторів ризику розвитку захворювань 3 т-типом респондентів. Визначення у подальшому в пацієнтів т-типу дозволить спрогнозувати ризик розвитку певної патології та запропонувати їм комплекс індивідуальних профрілактичних заходів.

Перспективи подальших досліджень полягають у проспективному вивченні стану здоров'я обстежених осіб. 


\section{Список літератури}

1. Агаджанян Н. А. Учение о здоровье и проблемы адаптации (теория и практика валеологических исследований) / Н. А. Агаджанян, Р. М. Баевский, А. П. Берсенева. - Ставрополь : СГУ, 2000. - 204 с.

2. Грузєва T. С. Інноваційна сутність та стратегічний і практичний потенціал нової європейської політики «Здоров'я - 2020» / Т. С. Грузєва // Вісник проблем біології і медицини. - 2014. - Т. 1 (110), Вип. 3. - С. 25-33.

3. Денефіль О. В. Сприйняття часу студентами за різних типів погоди / О. В. Денефріль // Одеський медичний журнал. - 2008. - Т. 110, № 6. - С. 7-9.

4. Моисеева Н. И. Время в нас и время вне нас / Н. И. Моисеева. - Л. : Лениздат, 1991. - 156 с.

5. Рибалка В. В. Індивід та особистість у психологічній теорії часу Б. Й. Цуканова / В. В. Рибалка // Практична психологія та соціальна робота. - 2008. - № 2. - С. 1-18.

6. Сурнина О. Е. Отмеривание временных интервалов людьми пожилого возраста / О. Е. Сурнина, Н. В. Антонова, О. Н. Капусняк // Физиология человека. - 2003. - Т. 29, № 1. - С. 86-89.

7. Цуканов Б. И. Время в психике человека : монография / Б. И. Цуканов. - Одесса : Астропринт, 2000. - 220 с.

8. Global Health Estimates 2016: Disease burden by Cause, Age, Sex, by Country and by Region, 2000-2016. - Geneva, World Health Organization, 2018.

9. Morbidity and prevalence of cardiovascular diseases in Ukraine: trends and forecasts untill 2025 / N. Terenda, Y. Petrashyk, N. Slobodian, L. Lishtaba // Georgian Medical News. - 2018. - Vol. 9 (282). - P. 79-82.

\section{References}

1. Agadzhanyan, N.A., Baevsky, R.M., \& Berseneva, A.P. (2000). Ucheniye o zdorovye i problemy adaptatsii (teoriya i praktika valeologicheskikh issledovaniy) [The doctrine of health and problems of adaptation (theory and practice of valeological research)]. Stavropol: SSU [in Russian].

2. Gruzeva, T.S. (2014). Innovatsiina sutnist ta stratehichnyi i praktychnyi potentsial novoi yevropeiskoi polityky "Zdorovia 2020" [Innovative essence and strategic and practical potential of the new European policy "Health - 2020"]. Visnyk problem biolohii i medytsyny - Bulletin of Problems of Biology and Medicine, 1 (110), 25-33 [in Ukrainian].

3. Denefil, O.V. (2008). Spryiniattia chasu studentamy za riznykh typiv pohody. [Perception of time by students for different types of weather]. Odeskyi medychnyi zhurnal - Odesa Medical Journal, 110 (6), 7-9 [in Ukrainian].

4. Moiseeva, N.I. (1991). Vremya v nas i vremya vne nas [Time in us and time outside us]. Leningrad: Lenizdat [in Russian]. 5. Rybalka, V.V. (2008). Indyvid ta osobystist u psykholohichnii teorii chasu B.Y. Tsukanova [Individual and personality in the psychological theory of time B.Y. Tsukanov]. Praktychna psykholohiia ta sotsialna robota - Practical Psychology and Social Work, 2, 1-18 [in Ukrainian].

6. Surnina, O.E., Antonova, N.V., \& Kapusnyak, O.N. (2003). Otmerivaniye vremennykh intervalov lyudmi pozhilogo vozrasta [Measurement of time intervals by elderly people]. Fiziologiya cheloveka - Human Physiology, 29 (1), $86-89$ [in Russian].

7. Tsukanov, B.I. (2000). Vremya v psikhike cheloveka [Time in the human psyche]. Odesa: Astroprint [in Ukrainian].

8. (2018). Global Health Estimates 2016: Disease burden by Cause, Age, Sex, by Country and by Region, 2000-2016. Geneva, World Health Organization.

9. Terenda, N., Petrashyk, Y., Slobodian, N., \& Lishtaba, L. (2018). Morbidity and prevalence of cardiovascular diseases in Ukraine: trends and forecasts untill 2025. Georgian Medical News, 9(282), 79-82.

\section{INDIVIDUAL TIME PERCEPTION AS AN EARLY PROGNOSTIC SIGN OF DISEASES DEVELOPMENT}

O. V. Denefil, O. A. Terenda, M. P. Protsyk, N. O. Terenda

I. Horbachevsky Ternopil National Medical University, Ternopil, Ukraine

Purpose: to reveal the risks of diseases development in young people in terms of individual time perception.

Materials and Methods. A questionnaire of 200 people aged from 18 to 22 (100 females and 100 males in each group) for the purpose of identifying the risk factors (RF) and for determining the individual index perception of time $(\tau)$ by the method of Tsukanov B. Y was conducted.

The questionnaire consists of grouped questions concerning the risk factors of pathology of the cardiovascular system, urinary system, gastrointestinal tract.

Results. Men with $\tau=0.7-0.8$ have a higher risk developing gastrointestinal tract diseases, as they drink more often alcohol and in greater amounts also they are more often overweight and are more often exposed to stress. There is a probability of higher risk of arterial hypertension development in women at $\tau=0.8-0.86$. Men with $\mathrm{\tau}=0.86-0.94$ compared to women, have a higher chance of kidney disease pathology development, because they are more often exposed to hypothermia and drink more water, thereby increasing pressure on the kidneys. Greater tendency to hypodynamics, predominance smoking, consumption of excess salty foods and significantly burdened hereditary history of cardiovascular pathology at $\tau=0.94-1.00$ in men indicates a high risk of developing future pathology of the heart vascular system (coronary heart disease and cerebrovascular disease).

Conclusion. The results indicate that there is a connection between certain risk factors of diseases development with $\mathrm{t}$-type in respondents. Defining the $\mathrm{t}$-type for patients will predict the risks of development of a certain pathology and will offer them a set of individual preventive measures. 
KEY WORDS: indicator of individual perception of time (t-type); morbidity; forecast; cardiovascular pathology.

Рукопис надійшов до редакції 09.01.2020 р.

Відомості про авторів:

Денефіль Ольга Володимирівна - доктор медичних наук, професор, завідувач кафедри патологічної фрізіології Тернопільського національного медичного університету імені І. Я. Горбачевського МОЗ України; тел.: +38(0352) 43-12-62.

Теренда Олександр Андрійович - студент III курсу медичного фракультету Тернопільського національного медичного університету імені І. Я. Горбачевського МОЗ України.

Процик Михайло Петрович - студент III курсу медичного фракультету Тернопільського національного медичного університету імені І. Я. Горбачевського МОЗ України.

Теренда Наталія Олександрівна - доктор медичних наук, доцент кафедри громадського здоров'я та управління охороною здоров'я Тернопільського національного медичного університету імені І. Я. Горбачевського МОЗ України; тел.: +38(0352) 52-72-33. 